\title{
Validation and realibility of Oral Health Impact Profile-14 questionnaire among pregnant woman
}

\author{
Anne Agustina Suwargiani*, Indra Mustika Setia Pribadi**, Wahyu Hidayat***, \\ Tadeus Arufan Jasrin**** \\ *Department of Dental Public Health Faculty of Dentistry Universitas Padjadjaran, Indonesia \\ **Department of Periodontic Faculty of Dentistry Universitas Padjadjaran, Indonesia \\ ***Department of Oral Medicine Faculty of Dentistry Universitas Padjadjaran, Indonesia \\ ****Department of Oral Biology Faculty of Dentistry Universitas Padjadjaran, Indonesia
}

\begin{abstract}
Introduction: The impact of oral health on quality of life of pregnant woman can be measured with the Oral Health Impact Profile-14 (OHIP-14). OHIP-14 is a measuring instrument that measures the functional limitations, physical pain, psychological discomfort, physical disability, psychological disorders, social disorder, and disability. Validity and reliability of a questionnaire is needed to measure the impact of dental health. Objective of the research was to get the data validity and OHIP-14 questionnaire reliability in pregnant woman. Methods: The research material that OHIP questionnaire 14 that has been adapted to the language and culture of Indonesia. Analysis of the questionnaire on the validity and realibility used correlation test. Research conducted by accidental sampling. Population study was pregnant woman who went to the Beautiful Clinic Banjaran District, Bandung, West Java Province, Indonesia. Sampel study was pregnant woman. The inclusion criteria of sample is in good general state of health, has no systemic abnormality and not being in analgesic therapy, and long-term antibiotic and exclusion criteria i.e. respondents who do not want to be sample research. Result: Validity OHIP-14 was the value of $\mathrm{R}$ calculated in the range from 0.495 to $0.647, \mathrm{r}$ value calculated in $95 \%$ confidence level was 0.374 and in $99 \%$ confidence level was 0.474 . The coefficient of reliability of 14 item instrument was 0.944 . Conclusion: From the statistic analysis, found that OHIP-14 questionnaire given to pregnant woman can be stated as a valid and reliable questionnaire.
\end{abstract}

Keywords: Validity, reliability, quality of life, OHIP-14, pregnant women

\section{INTRODUCTION}

During pregnancy, there is an increase in immune response and inflammatory mediators due to increased progesterone and estrogen. Changes in these hormonal levels, as well as oral hygiene and lifestyle habits, can lead to increased susceptibility of pregnant women, ${ }^{1}$ either to susceptibility to health conditions in general or to dental health. Measurement indicators of oral and dental health in pregnant women are increasingly being used to measure the impact of oral cavities on quality of life.

Corresponding author: Anne Agustina Suwargiani, Department of Dental Public Health Faculty of Dentistry Univ. Padjadjaran Jl. Sekeloa Selatan No. 1 Bandung, West Java-Indonesia, Phone/Fax: +6222-2504985, Email: anne.agustina@fkg.unpad.ac.id 
One of the most commonly used international indicators for measuring the effects of oral and dental health in pregnant women is Oral Health Impact Profile-14 (OHIP-14). OHIP-14 is a 14 questionnaire designed to measure a person's situation regarding the limited functionality, discomfort and functional limitations caused by dental and oral health conditions. ${ }^{2}$

This OHIP-14 Questionnaire came from a questionnaire of 49 questions based on theoretical model theory developed by WHO and adapted to oral health conditions by locker. ${ }^{3}$ In this model the consequences of hierarchical mouth disease are linked from the biological level (functional decline) to the level behavior (functional limits, discomfort and disability) and last to social level (disability). OHIP-14, despite being a short questionnaire, proved to have reliability; sensitive to change, and have adequate cross cultural consistency. $^{2}$

To measure the impact of dental health on pregnant women must first be tested the validity and reliability of OHIP-14 in the group of pregnant women. Test validity aims to determine the accuracy and accuracy of a measuring instrument, while the reliability is the degree of accuracy, precision, or accuracy indicated by the instrument measurement. ${ }^{4}$ The above description leads to the research objectives of how the validity and reliability of the OHIP-14 Questionnaire tested in the pregnant women's group.

\section{METHODS}

The research material was an OHIP-14 Questionnaire in accordance with the frequency of impact on a 5 point Likert scale code never (score 0 ), almost never (score 1), sometimes (score 2), quite frequent (score 3), and very often (score 4). Questions are answered on the basis of dental and oral health conditions within the limits of the past year. The questionnaire has already passed the language and cultural adaptation stage.

The adaptation and cultural stage is done by adjusting to the language and culture of Indonesia using translation techniques to maintain cross-cultural equality. ${ }^{2}$ In this procedure, the translation is independently made by two people, English language graduates and dentists with good English language skills, which are then discussed and resulted in an agreement on the Indonesian version of the questionnaire.

The research method used in this study is descriptive research that describes the condition of the population potluck. The population of the study were pregnant women who came to the clinic of Cantik in Banjaran, Bandung Regency, West Java Province, Indonesia. Sampling is taken based on accidental sampling. ${ }^{3}$ Inclusion criteria of research sample is pregnant women with good general health condition, aged 20-35 years, has no systemic abnormality and not being in analgesic therapy, and long-term antibiotic and exclusion

Table 1. Results of OHIP 14 validity test in pregnant women

\begin{tabular}{|c|c|c|c|c|c|}
\hline Instrument & $r$ count value & $R$ value (level Of significance 95\%) & Validity & R Value (level of significance 99\%) & Validity \\
\hline 1 & 0.589 & \multirow{14}{*}{0.374} & valid & \multirow{14}{*}{0.470} & valid \\
\hline 2 & 0.647 & & valid & & valid \\
\hline 3 & 0.562 & & valid & & valid \\
\hline 4 & 0.576 & & valid & & valid \\
\hline 5 & 0.495 & & valid & & valid \\
\hline 6 & 0.572 & & valid & & valid \\
\hline 7 & 0.627 & & valid & & valid \\
\hline 8 & 0.568 & & valid & & valid \\
\hline 9 & 0.615 & & valid & & valid \\
\hline 10 & 0.496 & & valid & & valid \\
\hline 11 & 0.617 & & valid & & valid \\
\hline 12 & 0.584 & & valid & & valid \\
\hline 13 & 0.628 & & valid & & valid \\
\hline 14 & 0.551 & & valid & & valid \\
\hline
\end{tabular}


Tabel 2 Result of realiability OHIP 14 in pregnant women

\begin{tabular}{cc}
\hline Instrument & Reliability \\
\hline 1 & 0,944 \\
2 & 0,944 \\
3 & 0,944 \\
4 & 0,944 \\
5 & 0,944 \\
6 & 0,944 \\
7 & 0,944 \\
8 & 0,944 \\
9 & 0,944 \\
10 & 0,944 \\
11 & 0,944 \\
12 & 0,944 \\
13 & 0,944 \\
14 & 0,944 \\
\hline
\end{tabular}

criteria i.e. respondents who do not want to be sample research. Research carried out for 1 month, obtained by pregnant women as many as 30 people. External validity test is done by using correlation test. Technique of reliability by using technique of retest test with test used correlation.

\section{RESULT}

Cross-cultural adaptation: Comparison between the English version of OHIP-14 and the Indonesian translation version does not show any concept difference. Fourteen OHIP questions are able to be answered by all respondents. ${ }^{3}$

The validity used in this study is external validity. ${ }^{3}$ The validity of the OHIP questionnaire in pregnant women includes questions about: (1) speech impediment, (2) difficulty in taste, (3) pain in the oral cavity, (4) discomfort during chewing, (5) anxiety about the problem of the oral cavity; (6) feeling tense, (7) the sense of satisfaction with the food consumed, (8) impaired mastication suddenly, (9) difficulty to relax and relax; (10) feel embarrassed, (11) irritability, (12) daily activities, (13) feel unsatisfactory life, (14) find it difficult to do anything, where all of these things are asked related to oral cavity problems in 30 pregnant women.

The result of validity by using correlation test at $95 \%$ and $99 \%$ significance level are in Table 2 showed the correlation test results in the correlation value ( $r$ ) count is in the range of values
0.495 up to 0.647 , with $r$ table values at $95 \%$ and $99 \%$ for 30 respondents are 0.374 and 0.470 . These results indicate a significant correlation value.

The Table 2 shows the correlation test results of the correlation (R) 0.944 , with the value of $\mathrm{R}$ table at $95 \%$ and $99 \%$ significance levels are 0.374 and 0.470 . These results indicate a significant correlation value.

\section{DISCUSSION}

OHIP-14 consists of 7 sub-scales (functional limitations, physical pain, psychological discomfort, physical limitations, psychological disorders, social disturbances, and disabilities). Questions about organ function and psychosocial impact related to problems involving oral and dental hygiene include 14 items of the instrument. ${ }^{4}$

Result of validity test in the form of correlation value ( $r$ ) count on result of data analysis of questionnaire of OHIP-14 point of instrument 1-14 shows $r$ value count in range $0.495-0.647$. The $R$ table value for 30 respondents at the $95 \%$ significance level is 0.374 . The result shows the value of $R$ arithmetic was greater than the value of $R$ table, this result indicates that the questionnaire is valid. This result is in accordance with that put forward by $\mathrm{Umar}^{5}$, that mentions how to do validity test that is by using correlation test, where the value of correlation in the value of $R$ arithmetic if greater than table $R$ then the value of $R$ arithmetic is significant, thus the instrument is valid. ${ }^{5}$ Validity at a $95 \%$ confidence level means that 95 percent of the 100 samples will have actual population values. ${ }^{6}$

The result of reliability test in the form of value of coefficient of reliability (Crohnbach's alpha) on result of data analysis of questionnaire of OHIP-14 point instrument $1-14$ shows $r$ value count 0.944 for all instrument items. This value shows the value of the realibility coefficient greater than the $r$ value of the table, this value indicates that all instrument items are reliable. This reliable value is consistent with that suggested by arikunto in Umar's book which states that the criticism value of this reliability can also be done by comparing the value of the realibility coefficient with $r$ table. If the value of the realibility coefficient is greater than the value of $r$ table, then an instrument is reliable. ${ }^{5}$ 
Measurement validity and reability are very important. This is very important in research, cause choosing a result of tool or instrument in planing a research study. Research study must be selected and develop. ${ }^{7}$

Validity test is the level of reliability and validity of the measuring instrument used. The instrument is said to be valid means to indicate the measuring instrument used to obtain the data is valid or can be used to measure what should be measured. ${ }^{8}$ Thus, a valid instrument is an instrument that is really appropriate to measure what to measure. ${ }^{8}$

Validity test is a testing step performed on the content of an instrument, with the aim of measuring the accuracy of the instrument (questionnaire) used in a study. Test reliability is the data to measure a questionnaire which is an indicator of the variable or construct. A questionnaire is said to be reliable or reliable if one's response to a statement is consistent or stable over time. ${ }^{9}$

A test or measuring instrument can be said to have high validity if the tool performs its measuring function, or provides a measuring result appropriate to the purpose of the measurement. Tests that produce data that are irrelevant to the purpose of measurement are said to be tests that have low validity. ${ }^{10}$

Instrument reliability test is required to know the extent to which measurement results can be trusted. Measurement of quality of life emphasizes the importance for the evaluation of health services especially on the impact of disease, injury, prevention, and treatment. Thus, the measurement of quality of life helps in investigating the social, emotional, physical effects of an illness and the treatment of everyday life, and the life of the patient to come. Disease and health services affect the quality of one's life. ${ }^{10}$

Validity and reliability of each item in the instrument is important. Research data that has been obtained and included in the program is important because it can affect the validity and reliability of research results.

\section{CONCLUSION}

From the statistic analysis, found that OHIP-14 questionnaire given to pregnant woman can be stated as a valid and reliable questionnaire.

\section{REFERENCES}

1. Lu HX, Xu W, Wong MCM, Wei TY, Feng XP. Impact of periodontal conditions on the quality of life of pregnant women: A crosssectional study. Health and Quality of Life Outcomes 2015;13:67.

2. Montero MJ, Bravo PM, Albaladejo MA, Hernández MLA, Rosel GEM. Validation the Oral Health Impact Profile (OHIP-14sp) for adults in Spain. Med Oral Patol Oral Cir Bucal 2009Jan1;14(1):E44-50.

3. Locker D, Quinonez C. Functional and psichosocial impacts of oral disorders in Canadian adult: A national population survey. J Can Dent Assoc 2009Sep;75(7):521.

4. Notoatmodjo S. Metodologi penelitian kesehatan. Jakarta: Rineka Cipta; 2010. p. 164-99.

5. Umar H. Metode riset dan bisnis. Jakarta: Gramedia; 2003. p. 77-83.

6. Lesaffre M, Feine J, Leroux B, Declerck D. Statistical and methodological aspect of oral health research. United Kingdom and India: Jhon Wiley and Sons, Ltd. Publ.; 2009.

7. Kathleen BGRN. Measurement reliability and validity. AORN J Des1997;66(6):1092-4.

8. Sarwono J. Metode penelitian kuantitatif dan kualitatif. Yogyakarta: Graha Ilmu; 2006.

9. Zahreza FSP, Sholeh M, Widyastuti N. Analisis kualitas layanan website BTKP DIY menggunakan metode Webqual 4.0. J Jaringan Komunikasi 2014jan:1(2):174-84.

10. Djuminten, Wilopo SA, Setiaji K. Uji reliabilitas instrumen kualitas hidup pada penderita kanker payudara. Berita Kedokteran Masyarakat 2011Sep:27(3):138-43.

11. Widodo PD. Reliabilitas dan validitas konstruk skala konsep diri untuk mahasiswa Indonesia. J Psikologi Universitas Diponegoro Jun 2006:3(1) 